\title{
Streptomyces coacervatus sp. nov., isolated from the intestinal tract of Armadillidium vulgare
}

\author{
Correspondence \\ Tohru Gonoi \\ gonoi@faculty.chiba-u.jp
}

\author{
Azusa Shibazaki, ${ }^{1,2}$ Yuta Omoto, ${ }^{2}$ Takuji Kudo, ${ }^{3}$ Takashi Yaguchi, ${ }^{2}$ \\ Akihiro Saito, ${ }^{1}$ Akikazu Ando, ${ }^{1}$ Yuzuru Mikami ${ }^{2}$ and Tohru Gonoi ${ }^{2}$ \\ ${ }^{1}$ Graduate School of Advanced Integration Science, Chiba University, 648 Matsudo, Matsudo, \\ Chiba 271-8510, Japan \\ ${ }^{2}$ Medical Mycology Research Center, Chiba University, Inohana 1-8-1, Chuo-ku, Chiba 260-8673, \\ Japan \\ ${ }^{3}$ JCM, RIKEN BioResource Center, Wako, Saitama 351-0198, Japan
}

\begin{abstract}
A Gram-staining-positive bacterium, designated $\mathrm{AS}-0823^{\top}$, which formed spiral spore chains on the aerial mycelium, was isolated from the intestinal tract of Armadillidium vulgare, a small terrestrial crustacean commonly found on the ground around houses in Japan. 16S rRNA gene sequence analysis showed that the isolate belonged to the genus Streptomyces and was most closely related to Streptomyces longisporus ISP $5166^{\top}$ (98.6\% $16 \mathrm{~S}$ rRNA gene sequence similarity), Streptomyces curacoi NBRC $12761^{\top}(98.4 \%)$ and Streptomyces griseoruber NBRC $12873^{\top}$ $(98.4 \%)$. The affiliation of strain AS-0823 ${ }^{\top}$ to the genus Streptomyces was supported by chemotaxonomic data: iso- $C_{16: 0}$, anteiso- $C_{15: 0}, C_{16: 0}$, iso- $C_{15: 0}$ and anteiso- $C_{17: 0}$ as the major cellular fatty acids, LL-diaminopimelic acid as the characteristic diamino acid in the peptidoglycan and the absence of mycolic acids. DNA-DNA hybridization and physiological and biochemical analysis supported the differentiation of strain AS- $0823^{\top}$ from S. longisporus JCM $4395^{\top}$. Therefore, strain AS- $0823^{\top}$ represents a novel species, for which the name Streptomyces coacervatus sp. nov. is proposed. The type strain is AS-0823 ${ }^{\top}\left(=\mathrm{IFM} 11055^{\top}=\mathrm{DSM} 41983^{\top}=\mathrm{JCM} 17138^{\top}\right)$.
\end{abstract}

The genus Streptomyces includes nearly 600 species with validly published names (http://www.bacterio.cict.fr/s/ streptomycesa.html). Streptomycetes are aerobic, Grampositive actinomycetes, of which most form an extensively branched substrate mycelium and aerial hyphae that typically differentiate into chains of spores (Anderson \& Wellington, 2001). Streptomycetes are a rich source of novel bioactive compounds. To find new strains able to produce useful bio-products, we attempted to isolate strains from unusual environments. We isolated a novel Streptomyces strain, designated AS- $0823^{\mathrm{T}}$, from the intestinal tract of Armadillidium vulgare (common pill woodlouse), a small terrestrial crustacean commonly found on the ground around houses in Japan that characteristically curls into a ball when threatened. The culture broth of strain AS- $0823^{\mathrm{T}}$ showed antifungal activity against Candida albicans and Aspergillus niger.

After collection of Armadillidium vulgare in Chiba City, Japan, the intestinal tract of the animal was dissected and washed. The tract contents were spread over brain heart

Abbreviations: ISP, International Streptomyces Project.

The GenBank/EMBL/DDBJ accession number for the 16S rRNA gene sequence of strain IFM $11055^{\top}$ is $\mathrm{AB} 500703$. infusion (BHI) agar (Difco) containing $2 \%$ glucose and $2 \%$ glycine and incubated at $28{ }^{\circ} \mathrm{C}$. A colony of strain AS- $0823^{\mathrm{T}}$ was obtained after 7 days. The isolate grew well on all tested International Streptomyces Project (ISP) media (ISP 2-7; Shirling \& Gottlieb, 1966), yeast-starch agar (Luedemann, 1971) and Bennett's agar (Jones, 1949) when incubated at $28{ }^{\circ} \mathrm{C}$ for 2 weeks. Particularly good growth was observed on ISP 4 and yeast-starch agar at $25-30{ }^{\circ} \mathrm{C}$. Cell morphology was observed under a light microscope (Nikon) at $\times 400$ magnification after incubation on each agar at $28{ }^{\circ} \mathrm{C}$. On all media, strain AS- $0823^{\mathrm{T}}$ produced a cream substrate mycelium and a cream aerial mycelium with white spores by day three. When cultured on agar or in liquid medium for longer than 2 weeks, the formation of an intracellular purple pigment was observed. In contrast, the closest phylogenetic relative, Streptomyces longisporus JCM $4395^{\mathrm{T}}$, produced a white substrate mycelium and a white aerial mycelium with white spores in all tested ISP media and grew well on yeaststarch agar and Bennett's agar at $25-30{ }^{\circ} \mathrm{C}$; no pigment was formed during culture for several weeks. Observation with a scanning electron microscope (S-3400N; Hitachi; Kageyama et al., 2004a, b) revealed that strain AS- $0823^{\mathrm{T}}$ produced a sparse aerial mycelium and spiny spores in spiral spore chains (Fig. 1), which contrasted clearly with the smooth spores in rectiflexibiles spore chains of S. longisporus (Al-Bari 


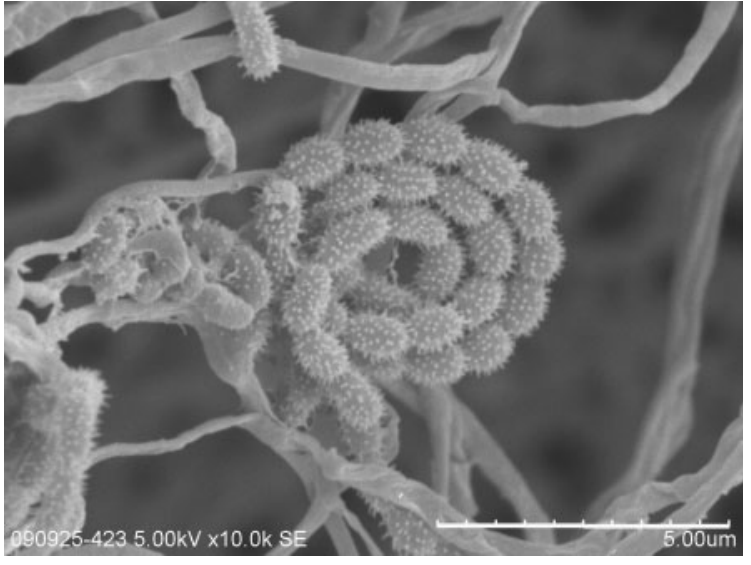

Fig. 1. Scanning electron micrograph of strain $A S-0823^{\top}$, showing sparse aerial mycelium and spiral chains of spiny spores. The isolate was cultured on yeast-starch agar at $28^{\circ} \mathrm{C}$ for 20 days. Bar, $5 \mu \mathrm{m}$.

et al., 2005). These characteristics apparently differentiate the two strains. Strain AS- $0823^{\mathrm{T}}$ was Gram-staining-positive using the method of Murray et al. (1994).

The 16S rRNA gene sequence was analysed as described by Kageyama et al. (2004a, b) using strains of related species of the genus Streptomyces that were selected using EzTaxon (Chun et al., 2007). Phylogenetic analysis was performed using MEGA4 (Tamura et al., 2007) after multiple alignment of data using CLUSTAL x version 2.0 (Thompson et al., 1994). Genetic distances were calculated using distance options according to the Kimura two-parameter model, Kimura \& Ohta, 1972) and clustering was determined with the neighbour-joining (Saitou \& Nei, 1987) and maximum-parsimony methods and evaluated using bootstrap values based on 1000 replications (Felsenstein, 1992; Fig. 2). The 16S rRNA gene sequence of strain AS- $0823^{\mathrm{T}}$ was a continuous stretch of $1496 \mathrm{bp}$. Sequence similarity calculations indicated that the closest relatives of the isolate were S. longisporus ISP $5166^{\mathrm{T}}$ (98.6\% $16 \mathrm{~S}$ rRNA gene sequence similarity), Streptomyces curacoi NBRC $12761^{\mathrm{T}}(98.4 \%)$ and Streptomyces griseoruber NBRC $12873^{\mathrm{T}}(98.4 \%$, Chun et al., 2007).

Analysis of the isomer of diaminopimelic acid $\left(\mathrm{A}_{2} \mathrm{pm}\right)$ was performed using hydrolysates of whole bacterial cells by TLC (Staneck \& Roberts, 1974). The whole-cell sugar pattern was analysed using whole-cell hydrolysates as described elsewhere (Lechevalier \& Lechevalier, 1980; Miyadoh, 2001). Mycolic acids were analysed by TLC (Minnikin et al., 1980) and GC (Springer et al., 1993; Klatte et al., 1994). For analysis of fatty acids, cells were cultured on $0.5 \%$ glucose, $0.5 \%$ starch and half-strength WL Nutrient Medium (Difco Laboratories) at $27{ }^{\circ} \mathrm{C}$ for $48 \mathrm{~h}$. Fatty acid methyl esters were prepared and analysed using the standard Microbial Identification System (MIDI) as described elsewhere (Klatte et al., 1994; Sasser, 1990; Kämpfer \& Kroppenstedt, 1996). The fatty acid profile comprised iso- $\mathrm{C}_{16: 0}(22.5 \%)$, anteiso- $\mathrm{C}_{15: 0}(19.1 \%), \mathrm{C}_{16: 0}$ $(12.0 \%)$, iso- $\mathrm{C}_{15: 0}(11.7 \%)$, anteiso- $\mathrm{C}_{17: 0}(10.3 \%)$, iso$\mathrm{C}_{17: 0}(6.7 \%)$, iso- $\mathrm{C}_{14: 0}(4.2 \%), \mathrm{C}_{15: 0}(3.5 \%), \mathrm{C}_{14: 0}$ $(1.2 \%)$, iso- $\mathrm{C}_{17: 1}(1.1 \%)$, anteiso- $\mathrm{C}_{17: 1}(0.5 \%)$, cyclo$\mathrm{C}_{17: 0}(0.4 \%)$, iso- $\mathrm{C}_{16: 1}(0.4 \%)$ and iso- $\mathrm{C}_{18: 0}(0.3 \%)$. Other results of the chemotaxonomic analysis are given in the species description. The chemotaxonomic characteristics were consistent with the assignment of strain AS- $0823^{\mathrm{T}}$ to the genus Streptomyces.

The DNA G + C content of strain AS- $0823^{\mathrm{T}}$ was determined by HPLC (Tamaoka \& Komagata, 1984) and was calculated to be $73.5 \mathrm{~mol} \%$, which supported the affiliation of the isolate to the order Actinomycetales. DNA-DNA hybridization was performed by the photobiotin method as described by Ezaki et al. (1989). DNA-DNA relatedness between strain AS- $0823^{\mathrm{T}}$ and S. longisporus JCM $4395^{\mathrm{T}}$ was $15.5 \pm 0.5 \%(\mathrm{sD}, n=2)$, which was well below the cut-off point of $70 \%$ for species delineation that was recommended by Wayne et al. (1987).

Because S. curacoi has synonymy with $S$. coeruleorubidus (Labeda \& Lyons, 1991; also see http://www.jcm.riken.go.jp/), phenotypic characterization of strain AS- $0823^{\mathrm{T}}$ was performed alongside S. coeruleorubidus JCM $4359^{\mathrm{T}}$ as well as S. longisporus JCM $4395^{\mathrm{T}}$ and S. griseoruber JCM $4642^{\mathrm{T}}$. Carbon source utilization tests were performed as described by Shirling \& Gottlieb (1966). Inhibitory concentrations of $\mathrm{NaCl}$ were determined as described by Tresner et al. (1968), using ISP 4 as the basal medium. Nitrate reduction was tested using nitrate broth (Eiken Chemical Co.) according to the manufacturer's instructions. Hydrogen sulfide production was determined as described by Tresner \& Danga (1958). The results are presented in Table 1. Strain AS- $0823^{\mathrm{T}}$ could be distinguished from S. longisporus JCM $4395^{\mathrm{T}}$ and the other type strains by utilization of several carbon sources, growth temperature, inhibitory concentration of $\mathrm{NaCl}$, effect of $\mathrm{pH}$ on growth, nitrate reduction, melanin and hydrogen sulfide production and mycelium colour (Kämpfer et al., 1991).

We verified whether the isolate produced bioactive-substance(s) with anti-fungal activities. The isolate was cultured in WL Nutrient Medium containing $0.1 \%$ glycerol and $1 \%$ soluble starch at $28{ }^{\circ} \mathrm{C}$ for 3 days. A methanol extract of the cells was assayed using the paper disc agar diffusion method (NCCLS, 1995) with Aspergillus niger IFM 5368 and C. albicans ATCC 90028 as reference strains. A biologically active

Fig. 2. Neighbour-joining phylogenetic tree, based on 1436 bp $16 \mathrm{~S}$ rRNA gene sequences, showing the relationships between Streptomyces coacervatus sp. nov. IFM $11055^{\top}$ and closely related strains of species of the genus Streptomyces. Bootstrap values based on 1000 replications are shown at branch nodes. Asterisks indicate that the corresponding nodes were recovered in trees generated with the maximum-parsimony algorithm. Bar, 5 substitutions per 1000 nucleotide positions. 


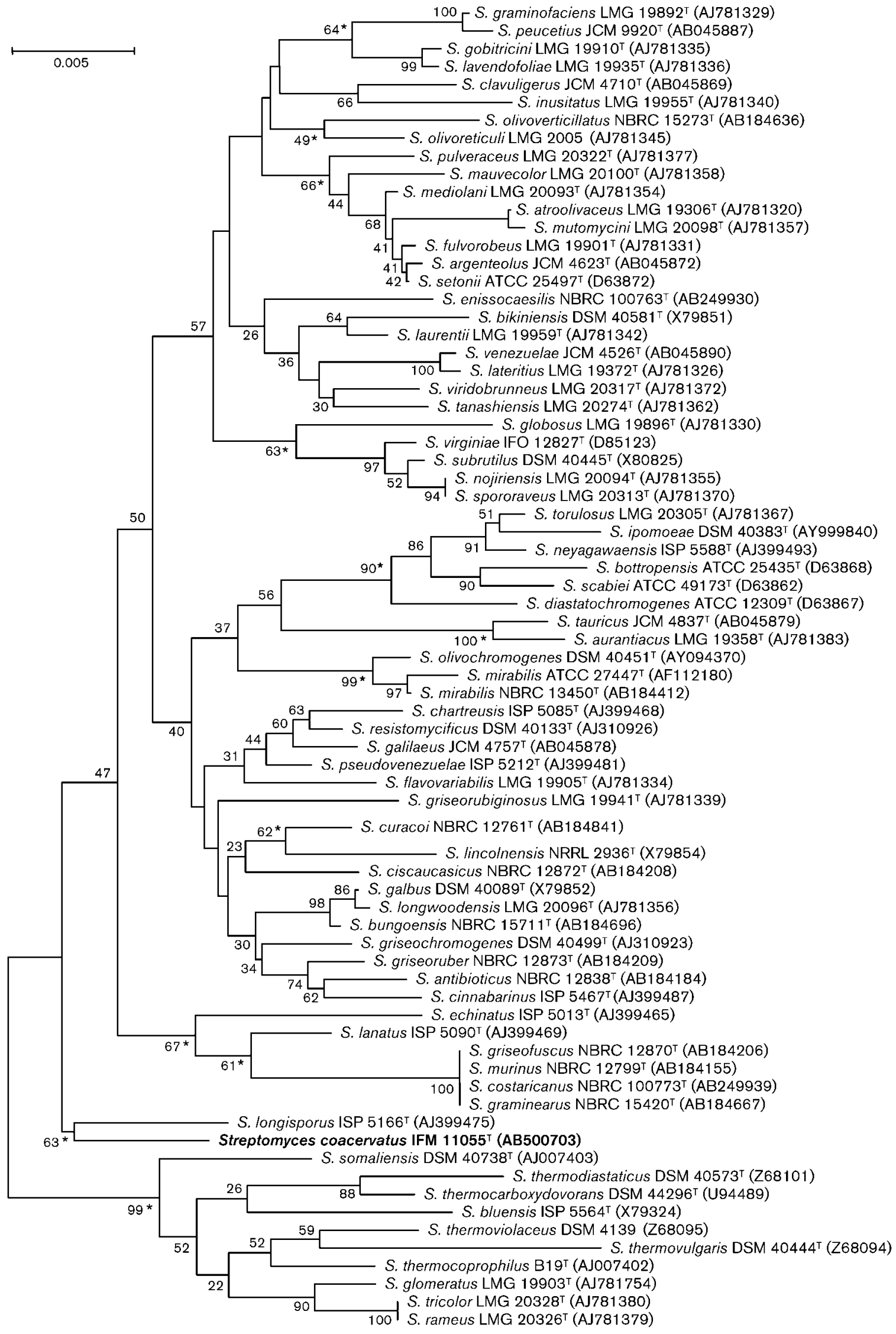


substance was separated further using a silica gel column. The UV spectrum of the active fraction showed peaks of absorbance at 318-321, 333-337 and 350-354 nm in methanol, which suggested that the bioactive compound contained a pentane molecular structure (Okami et al., 1954).

Phylogenetic, chemotaxonomic and phenotypic analysis demonstrated that strain AS- $0823^{\mathrm{T}}$ belongs to the genus Streptomyces but is not a member of any of the recognized species in the genus. Therefore, strain AS- $0823^{\mathrm{T}}$ is classified in a novel species, for which the name Streptomyces coacervatus sp. nov. is proposed.

Table 1. Characteristics differentiating strain $A S-0823^{\top}$ from closely related type strains of species of the genus Streptomyces

Strains: 1 , Streptomyces coacervatus sp. nov. AS- $0823^{\mathrm{T}} ; 2$, S. longisporus JCM $4395^{\mathrm{T}}$; 3, S. coeruleorubidus JCM $4359^{\mathrm{T}} ; 4$, S. griseoruber JCM $4642^{\mathrm{T}}$. All data were taken from this study. All strains degrade adenine, hypoxanthine, starch and gelatin and grow well on Lasparagine and L-cysteine $(1 \%, \mathrm{w} / \mathrm{v})$ as sole nitrogen sources, on $\mathrm{D}$ fructose, sucrose, L-rhamnose and inositol as sole carbon sources, at $20{ }^{\circ} \mathrm{C}$ and at $\mathrm{pH}$ 6-9. None of the strains produce diffusible pigment on ISP 5. + +, Good growth; +, growth; - , no growth.

\begin{tabular}{|c|c|c|c|c|}
\hline Characteristic & 1 & 2 & 3 & 4 \\
\hline \multicolumn{5}{|l|}{ Sole carbon sources } \\
\hline L-Arabinose & ++ & - & ++ & + \\
\hline D-Xylose & ++ & ++ & + & - \\
\hline Raffinose & ++ & ++ & ++ & - \\
\hline D-Mannitol & ++ & ++ & ++ & - \\
\hline \multicolumn{5}{|l|}{ Growth at: } \\
\hline $10{ }^{\circ} \mathrm{C}$ & + & - & - & - \\
\hline $28{ }^{\circ} \mathrm{C}$ & ++ & ++ & + & ++ \\
\hline $37{ }^{\circ} \mathrm{C}$ & ++ & ++ & + & + \\
\hline \multicolumn{5}{|l|}{ Growth with: } \\
\hline $4 \% \mathrm{NaCl}$ & ++ & ++ & ++ & - \\
\hline $7 \% \mathrm{NaCl}$ & - & - & + & - \\
\hline \multicolumn{5}{|l|}{ Growth at (ISP 4): } \\
\hline pH 5 & - & - & + & - \\
\hline $\mathrm{pH} 10$ & - & + & + & + \\
\hline pH 11 & - & - & + & + \\
\hline Nitrate reduction & + & - & ++ & - \\
\hline \multicolumn{5}{|c|}{ Melanin production on: } \\
\hline ISP 6 & - & - & + & ++ \\
\hline ISP 7 & - & + & - & + \\
\hline $\mathrm{H}_{2} \mathrm{~S}$ production & - & - & + & ++ \\
\hline \multicolumn{5}{|c|}{ Mycelium colour (ISP 4)* } \\
\hline Aerial & C & $\mathrm{W}$ & $\mathrm{T}$ & YW \\
\hline Substrate & C & $\mathrm{w}$ & $\mathrm{BR}$ & $\mathrm{P}$ \\
\hline \multicolumn{5}{|c|}{ Diffusible pigment on:* } \\
\hline ISP 6 & None & None & $\mathrm{BL}$ & $\mathrm{BR}$ \\
\hline
\end{tabular}

${ }^{\star}$ BL, Black; BR, brown; C, cream; P, pink, T, turquoise; YW, yellowish white.

\section{Description of Streptomyces coacervatus sp. nov.}

Streptomyces coacervatus (co.a.cer.va'tus. L. masc. part. adj. coacervatus heaped together, heaped up, collected in a mass, referring to the colony morphology on agar plates).

Aerobic, Gram-staining-positive actinomycete that forms an extensively branched substrate mycelium and sparse aerial hyphae that differentiate into spiral chains of spores. Growth occurs at $10-37{ }^{\circ} \mathrm{C}$, at $\mathrm{pH} 6-9$ and with $4 \% \mathrm{NaCl}$. Good growth occurs on all tested ISP media (ISP 2-7), yeast-starch agar and Bennett's agar at $28{ }^{\circ} \mathrm{C}$. Cream aerial mycelia are formed on all media. Purple pigments are formed during cultivation at $28{ }^{\circ} \mathrm{C}$ for 2 weeks. Contains LL-diaminopimelic acid, but not meso-diaminopimelic acid, mycolic acid or characteristic sugars in the cell wall (wall chemotype I sensu Lechevalier \& Lechevalier, 1980). The fatty acids are iso- $\mathrm{C}_{16: 0}$, anteiso- $\mathrm{C}_{15: 0}, \mathrm{C}_{16: 0}$, iso$\mathrm{C}_{15: 0}$, anteiso- $\mathrm{C}_{17: 0}$, iso- $\mathrm{C}_{17: 0}$, iso- $\mathrm{C}_{14: 0}, \mathrm{C}_{15: 0}, \mathrm{C}_{14: 0}$, iso$\mathrm{C}_{17: 1}$, anteiso- $\mathrm{C}_{17: 1}$, cyclo- $\mathrm{C}_{17: 0}$, iso- $\mathrm{C}_{16: 1}$ and iso- $\mathrm{C}_{18: 0}$. Degrades adenine, hypoxanthine, starch and gelatin, reduces nitrate and utilizes L-arabinose, D-xylose, raffinose, D-mannitol, D-fructose, sucrose, L-rhamnose and inositol. The DNA G +C content of the type strain is $73.5 \mathrm{~mol} \%$.

The type strain is AS- $0823^{\mathrm{T}}\left(=\mathrm{IFM} 11055^{\mathrm{T}}=\mathrm{DSM} 41983^{\mathrm{T}}=\right.$ JCM $17138^{\mathrm{T}}$ ), isolated from the intestinal tract of Armadillidium vulgare in Chiba City, Japan.

\section{Acknowledgements}

We are grateful to Dr J. P. Euzéby, Laboratoire de Bactériologie, École Nationale Vétérinaire de Toulouse, France, for assistance with etymology. This work was supported by a grant from the Ministry of Education, Culture, Sports, Science and Technology of the Japanese government to Y.M. and T. G. (21-106003).

\section{References}

Al-Bari, M. A., Bhuiyan, M. S., Flores, M. E., Petrosyan, P., García-Varela, M. \& Islam, M. A. (2005). Streptomyces bangladeshensis sp. nov., isolated from soil, which produces bis-(2-ethylhexyl)phthalate. Int J Syst Evol Microbiol 55, 1973-1977.

Anderson, A. S. \& Wellington, E. M. (2001). The taxonomy of Streptomyces and related genera. Int J Syst Evol Microbiol 51, 797814.

Chun, J., Lee, J.-H., Jung, Y., Kim, M., Kim, S., Kim, B. K. \& Lim, Y.-W. (2007). EzTaxon: a web-based tool for the identification of prokaryotes based on $16 \mathrm{~S}$ ribosomal RNA gene sequences. Int J Syst Evol Microbiol 57, 2259-2261.

Ezaki, T., Hashimoto, Y. \& Yabuuchi, E. (1989). Fluorometric deoxyribonucleic acid-deoxyribonucleic acid hybridization in microdilution wells as an alternative to membrane filter hybridization in which radioisotopes are used to determine genetic relatedness among bacterial strains. Int J Syst Bacteriol 39, 224-229.

Felsenstein, J. (1992). Estimating effective population size from samples of sequences: a bootstrap Monte Carlo integration method. Genet Res 60, 209-220.

Jones, K. L. (1949). Fresh isolates of actinomycetes in which the presence of sporogenous aerial mycelia is a fluctuating characteristic. J Bacteriol 57, 141-145. 
Kageyama, A., Poonwan, N., Yazawa, K., Mikami, Y. \& Nishimura, K. (2004a). Nocardia asiatica sp. nov., isolated from patients with nocardiosis in Japan and clinical specimens from Thailand. Int J Syst Evol Microbiol 54, 125-130.

Kageyama, A., Yazawa, K., Nishimura, K. \& Mikami, Y. (2004b). Nocardia inohanensis sp. nov., Nocardia yamanashiensis sp. nov. and Nocardia niigatensis sp. nov., isolated from clinical specimens. Int J Syst Evol Microbiol 54, 563-569.

Kämpfer, P. \& Kroppenstedt, R. M. (1996). Numerical analysis of fatty acid patterns of coryneform bacteria and related taxa. Can J Microbiol 42, 989-1005.

Kämpfer, P., Kroppenstedt, R. M. \& Dott, W. (1991). A numerical classification of the genera Streptomyces and Streptoverticillium using miniaturized physiological tests. J Gen Microbiol 137, 1831-1891.

Kimura, M. \& Ohta, T. (1972). On the stochastic model for estimation of mutational distance between homologous proteins. J Mol Evol 2, 87-90.

Klatte, S., Rainey, F. A. \& Kroppenstedt, R. M. (1994). Transfer of Rhodococcus aichiensis Tsukamura 1982 and Nocardia amarae Lechevalier and Lechevalier 1974 to the genus Gordona as Gordona aichiensis comb. nov. and Gordona amarae comb. nov. Int J Syst Bacteriol 44, 769-773.

Labeda, D. P. \& Lyons, A. J. (1991). Deoxyribonucleic acid relatedness among species of the "Streptomyces cyaneus" cluster. Syst Appl Microbiol 14, 158-164.

Lechevalier, M. P. \& Lechevalier, H. A. (1980). The chemotaxonomy of actinomycetes. In Actinomycete Taxonomy, pp. 227-291. Edited by A. Dietz \& D. W. Thayer. Fairfax, VA: Society for Industrial Microbiology.

Luedemann, G. M. (1971). Micromonospora purpureochromogenes (Waksman and Curtis 1916) comb. nov. (subjective synonym: Micromonospora fusca Jensen 1932). Int J Syst Bacteriol 21, 240-247.

Minnikin, D. E., Hutchinson, I. G., Caldicott, A. B. \& Goodfellow, M. (1980). Thin-layer chromatography of methanolysates of mycolic acid-containing bacteria. J Chromatogr A 188, 221-233.

Miyadoh, M. (2001). Identification procedure at the genus level. In Identification Manual of Actinomycetes, pp. 9-19. Edited by S. Miyadoh, M. Hamada, K. Hotta, T. Kudo, A. Seino, K. Suzuki \& A. Yokota. Tokyo: Business Center for Academic Societies Japan.

Murray, R. G. E., Doetsch, R. N. \& Robinow, C. F. (1994). Determinative and cytological light microscopy. In Methods for General and Molecular Bacteriology, pp. 22-41. Edited by P. Gerhardt, R. G. E. Murray, W. A. Wood \& N. R. Krieg. Washington, DC: American Society for Microbiology.
NCCLS (1995). Methods for Dilution Antimicrobial Susceptibility Tests for Bacteria that Grow Aerobically. Approved Standard M7-A4. Wayne, PA: National Committee for Clinical Laboratory Standards.

Okami, Y., Utahara, R., Nakamura, S. \& Umezawa, H. (1954). Studies on antibiotic actinomycetes. IX. On Streptomyces producing a new antifungal substance mediocidin and antifungal substances of fungicidin-rimocidin-chromin group, eurocidin group and trichomycin-ascosin-candicidin group. J Antibiot (Tokyo) 7, 98-103.

Saitou, N. \& Nei, M. (1987). The neighbor-joining method: a new method for reconstructing phylogenetic trees. Mol Biol Evol 4, 406-425.

Sasser, M. (1990). Identification of bacteria by gas chromatography of cellular fatty acids. USFCC Newsl 20, 16.

Shirling, E. B. \& Gottlieb, D. (1966). Methods for characterization of Streptomyces species. Int J Syst Bacteriol 16, 313-340.

Springer, B., Kirschner, P., Rost-Meyer, G., Schröder, K. H., Kroppenstedt, R. M. \& Böttger, E. C. (1993). Mycobacterium interjectum, a new species isolated from a patient with chronic lymphadenitis. J Clin Microbiol 31, 3083-3089.

Staneck, J. L. \& Roberts, G. D. (1974). Simplified approach to identification of aerobic actinomycetes by thin-layer chromatography. Appl Microbiol 28, 226-231.

Tamaoka, J. \& Komagata, K. (1984). Determination of DNA base composition by reverse-phase high-performance liquid chromatography. FEMS Microbiol Lett 25, 125-128.

Tamura, K., Dudley, J., Nei, M. \& Kumar, S. (2007). MEGA4: molecular evolutionary genetics analysis (MEGA) software version 4.0. Mol Biol Evol 24, 1596-1599.

Thompson, J. D., Higgins, D. G. \& Gibson, T. J. (1994). CLUSTAL W: improving the sensitivity of progressive multiple sequence alignment through sequence weighting, position-specific gap penalties and weight matrix choice. Nucleic Acids Res 22, 4673-4680.

Tresner, H. D. \& Danga, F. (1958). Hydrogen sulfide production by Streptomyces as a criterion for species differentiation. J Bacteriol 76, 239-244.

Tresner, H. D., Hayes, J. A. \& Backus, E. J. (1968). Differential tolerance of streptomycetes to sodium chloride as a taxonomic aid. Appl Microbiol 16, 1134-1136.

Wayne, L. G., Brenner, D. J., Colwell, R. R., Grimont, P. A. D., Kandler, O., Krichevsky, M. I., Moore, L. H., Moore, W. E. C., Murray, R. G. E. \& other authors (1987). International Committee on Systematic Bacteriology. Report of the ad hoc committee on reconciliation of approaches to bacterial systematics. Int J Syst Bacteriol 37, 463464. 